\title{
POLLEN TRANSCRIPTOME AND PROTEOME: MOLECULAR AND FUNCTIONAL ANALYSIS
}

\author{
Katarzyna RAFINSKA, Krzysztof ZIENKIEWICZ, Elzbieta BEDNARSKA \\ Department of Cell Biology, Nicolaus Copernicus University in Torun
}

DOI: $10.2478 / \mathrm{v} 10052-010-0003-9$

\begin{abstract}
Summary: The pollen grain, because of its unique structural organization, is an extremely useful experimental model in cytological, molecular as well as in genetic studies. Due to the ease of pollen grain isolation, their sorting as well as simple extraction of their DNA, RNA and proteins, male gametophyte cells of angiosperms are presently one of the most intensively studied plant cells. Important and rapid progress in the development of experimental tools for genome exploration caused a significant increase in the number of reports concerning different aspects of gene expression during microsporogenesis and microgametogenesis in angiosperm plants. In this review we present the current knowledge of the pollen transcriptome and proteome during different stages of male gametophyte development, especially in Arabidopsis thaliana. Most of the results presented here were obtained in experiments carried out using microarrays, which were designed on the basis of the known sequence of the Arabidopsis genome.
\end{abstract}

Key words: pollen, transcriptome, proteome, Arabidopsis

\section{INTRODUCTION}

The pollen grain is the male gametophyte and is the generative phase in the life cycle of higher plants. Two processes contribute to its development: microsporogenesis and microgametogenesis. Microsporogenesis encompasses meiosis which takes place in microspore stem cells (microsporocytes). As a result, a tetrad of haploid microspores is formed which, after liberation, increase their volume and differentiate into the pollen grain. Microgametogenesis begins with an asymmetric microspore division (meiotic division I), resulting in formation of a two-cell pollen grain. Pollen cells differ in respect to morphology and physiology a large vegetative cell which takes up most of the pollen grain volume is much more active than the small generative cell during pollen development [87]. At the 
final stage of gametophyte development the generative cell divides into two sperm cells (meiotic division II). In the three-cell pollen grains the mitotic division takes place during the development of pollen in the anther, whereas in the two-cell grains the mitotic division occurs during growth of the pollen tube in the pistil. Before liberation of the pollen grains from the anthers they are dehydrated, which is accompanied by inhibition of transcriptional activity of pollen cells. After pollination the pollen grain is hydrated and germinates into the pollen tube. The pollen tube growing from the aperture is the fastest growing plant cell and serves to transfer the male gametes into the embryo sac.

The pollen grain and the pollen tube, because of the ease of isolation and in vitro culture, are an excellent model for analyzing many fundamental biological processes such as: cell polarization, determination of development, cell cycle regulation, cell signaling, directional growth and regulation of gene expression. A basic step towards understanding the mechanisms which regulate these processes is to isolate the transcriptome and proteome of the male gametophyte. The relatively simple isolation of RNA and proteins from a pure population of pollen grains makes it possible to analyze the expression of genes of an essentially single cell i.e. a vegetative cell.

Development of the male gametophyte is controlled by two successive developmental programs. Depending on the developmental stage at which the genes are transcribed they have been divided into two classes: early genes and late genes. The transcripts of early genes appear just after meiosis, and their level later decreases considerably in mature pollen grains. Transcripts of late genes, detected only after the first mitotic division, accumulate during the maturation of the pollen grain until it reaches complete maturity. These transcripts constitute a pool of socalled long-lived mRNA, which is not translated until the moment of germination of the pollen tube [9,77]. This pool stored mainly in the cytoplasm of the vegetative cell in the form of poly(A)RNA [86], is able to survive dehydration and the successive rehydration during pollination of the pistil. It is a ready-made template for protein synthesis during the germination of the pollen tube. The mature pollen grain is thus provided with a genetic program executed during the pollination and early stages of pollen tube growth [77].

The generative cell and sperm cells are characterized by a low volume of cytoplasm and strongly condensed chromatin in the nucleus. They show a low level of expression even though in the two-cell pollen grains and also in the generative cell poly(A)RNA, transcripts may be stored [86]. Sperm cells predominantly synthesize secretory or membrane proteins which are believed to be related to the recognition on the cell-cell level during fertilization [24]. 


\section{TRANSCRIPTOME OF THE ARABIDOPSIS THALIANA POLLEN GRAIN}

A convenient model for analyzing the genetic bases of pollen grain differentiation and the germination and growth of the pollen tube is Arabidopsis, a plant producing tricellular pollen grains made up of a large generative cell and two small sperm cells. The sequencing of the genome of this species was accompanied by the development of molecular biology techniques. This made it possible to identify genes which are expressed at a high level in pollen grains and those which are pollen-specific, which allowed better understanding of the mechanisms involved in the process of development of the male gametophyte in angiosperms.

A large scale analysis of the A. thaliana pollen grain transcriptome was carried out using two methods: SAGE (Serial Analysis of Gene Expression) and microarrays. Initially, the former had an advantage as knowledge of the gene sequence of the analyzed organism was not necessary. This method allows the detection of the expression of a gene which is not annotated. The expression of 4211 genes was demonstrated in the pollen grain and compared to the genes undergoing expression in somatic tissues [45]. Over $40 \%$ of the detected transcripts were found to encode genes involved in cell wall biosynthesis. A low level of expression in comparison to leaves is, on the other hand, found for genes which are involved in the synthesis of other proteins, including those involved in basal energy metabolism. The number of molecules of transcripts of genes with a high level of expression in the male gametophyte was found to be very high. Genes expressed as more than 100 copies in one cell were found to constitute $58 \%$ of the total number of transcripts [45].

The sequencing of the A. thaliana genome and the introduction of the microarray technique in which each gene is isolated by a set of molecular probes enables the determination of the pollen transcriptome of this species [69]. So far four research groups have been involved in this task (Table 1).

The first research performed on an Affymetrix Gene Chip AG, which represents the sequence of almost 1/3 of the Arabidopsis genome (8200 genes) yielded considerable discrepancies as to the number of genes whose transcripts are present in the mature pollen grain. One of the research groups identified the transcripts of 992 genes of which almost $40 \%$ were described as pollen-specific [35]. However, another group detected the transcripts of 1584 genes and determined that $90 \%$ of them also are expressed in sporophyte tissues which constitutes over $60 \%$ of the genes undergoing constant expression in the sporophyte [5]. Among 469 genes having a high level of expression in the gametophyte, 162 were classified as pollen specific. The reason for the discrepancies in the number of pollen specific genes [9] is found by comparison of the pollen transcriptome with the transcriptome of individual organs, such as leaves, roots, seedlings [5], the transcriptome of the whole plant in successive 
developmental stages [36], and also by comparison with the transcriptomes of different $A$. thaliana genotypes. The number of genes undergoing expression in the pollen grain is 30 to $60 \%$ lower than in sporophyte tissues [5,77]. Attention was paid to the differences between the pattern of expression of genes in the male gametophyte and vegetative tissues [5]. Most genes with an average or high level of expression in seedlings showed a low level of expression in pollen grains and vice versa - those with a low level of expression in seedlings showed a high level of expression in the gametophyte. In the pollen grain 3 times fewer genes were expressed than in any sporophyte tissue [5]. These analyses show that the number of genes undergoing expression in the pollen grain ranges between 3500 and 5500 [77].

TABLE 1. Number of genes whose transcripts occur in mature A. thaliana pollen grains.

\begin{tabular}{|c|c|c|c|c|}
\hline Research group & Year & $\begin{array}{c}\text { Species } \\
\text { (ecotype) }\end{array}$ & Microarray used & Number of genes \\
\hline Honys i Twell [36] & 2003 & $\begin{array}{c}\text { Arabidopsis } \\
\text { (Landsberg erecta) }\end{array}$ & Affymetrix AG & 992 \\
\hline Becker i wsp. [5] & 2003 & $\begin{array}{c}\text { Arabidopsis } \\
\text { (Columbia) }\end{array}$ & Affymetrix AG & 1584 \\
\hline Honys i Twell [37] & 2004 & $\begin{array}{c}\text { Arabidopsis } \\
\text { (Landsberg erecta) }\end{array}$ & $\begin{array}{c}\text { Affymetrix } \\
\text { ATH1 }\end{array}$ & 7235 \\
\hline Pina i wsp. [59] & 2005 & $\begin{array}{c}\text { Arabidopsis } \\
\text { (Columbia) }\end{array}$ & $\begin{array}{c}\text { Affymetrix } \\
\text { ATH1 }\end{array}$ & 6587 \\
\hline
\end{tabular}

The use of newer ATH1 microarrays encompassing $80 \%$ of the A. thaliana genome, has allowed a more detailed analysis of the expression pattern and a better estimation of the number of genes expressed in a maturing pollen grain. Using this microarray the presence of the transcripts of 6587 genes was demonstrated which constituted $29 \%$ of the sequences on the chip [58]. However, transcripts of different vegetative tissues constituted a significantly higher percentage of the microarray (e.g. flowers 68\%, leaves 62\%, shoots 68\%, seedlings 69\%), which means that in the male gametophyte over $50 \%$ fewer genes are expressed than in vegetative tissues. In the male gametophyte $11 \%$ of genes (739) expressed are pollen-specific [58]. This is much more than in vegetative organs such as leaves, shoots and seedlings where the percentages of the specific genes are respectively $2 \%, 4 \%$ and $6 \%$. Of the $26 \%$ of pollen genes which have been described as highly active as many as $1 / 3$ were specific and over $3 / 4$ of these specific genes had a high level of expression. On the basis of these results and assuming that the A. thaliana 
genome encodes 28000 genes, 8200 genes were estimated to undergo expression in pollen grains [58].

Using Affymetrix ATH1 microarrays successive stages of male gametophyte development were analyzed and 13977 genes undergoing specific expression in at least one stage were identified, of which $9.7 \%$ were pollen specific [37]. Most genes are expressed in the two earliest stages -11565 in the microspore and 11909 in the two-cell pollen grain. After division of the generative cell into two sperm cells in the pollen grain the transcripts of 8788 genes were found, while in mature pollen grain only 7235 gene transcripts. The large numbers of genes which undergo expression in the early and late phase of male gametophyte development probably are housekeeping genes [77]. The number of pollen specific genes varied from 857 in the two cell stage to 625 in the mature pollen grain. In spite of the decrease of the number of different mRNA molecules, the percentage of transcripts specific for the male gametophyte increased from $6.9 \%$ in the microspore to $8.6 \%$ in the mature pollen grain. According to the estimations the total number of genes undergoing expression in the maturing $A$. thaliana pollen grain may be as large as 17000 [36].

As transcriptomes of new types of cells and tissues of Arabidopsis have become known the number of pollen grain specific genes decreased to $5.6 \%$, much lower than initially assumed. They are, in general, expressed at a very high level and constitute the so-called group of late pollen genes. The average level of expression of late pollen genes is higher than that of constitutive genes. Considering the transcription pattern of pollen grains unspecific genes expressed at a high level should be noted. In this group genes are included for which the maximum expression in the male gametophyte is at least five times higher than the maximum expression in sporophyte tissues [77]. 1364 such genes have been identified, i.e. 9.7\% of genes undergoing expression during the development of the male gametophyte. Among genes not specific for pollen 1084 were expressed as early pollen genes and 1014 as late pollen genes.

The number of genes undergoing transcription in A. thaliana pollen grains identified by various research groups differs considerably, probably due to the use of different ecotypes for the analysis, different growth conditions of the plants, methods of isolation and sorting of pollen grains, and also different experimental conditions and methods of data analysis [19]. The ATH1 microarray was designed on the basis of the sequence of the genome of ecotype Columbia. Thus the analysis of pollen grains of the Columbia ecotype is the truest reflection of the real situation. Comparative analyses of eight $A$. thaliana ecotypes indicate considerable differences, partly due to posttranslational modifications and partly to the occurrence of different alleles of the same gene [18]. Genetic differences between different $A$. thaliana ecotypes have been confirmed by the analysis of the transcriptome of the growth apex of the Columbia and Landsberg ecotypes, also performed on an ATH1 microarray [69]. 
Using FACS (fluorescence activated cell sorting) it was also possible to analyze the transcriptome of Arabidopsis thaliana sperm cells. On an ATH1 microarray, transcripts of 5829 genes were detected, of which 2400 had a high level of expression. Comparative analysis showed that the transcripts of 4757 genes were shared between sperm cells and seedlings [12].

At the present stage of investigations, in spite of considerable discrepancies of the results a general pattern of gene expression in differentiating and mature male gametophyte of $A$. thaliana can be outlined. The microspore transcriptome more closely resembles the transcriptome of undifferentiated somatic cells cultured in suspension (correlation coefficient $(R)=0.474$ ) than the transcriptome of a mature pollen grain $(R=0.194)$ [37]. This indicates a change in the genetic program of the cells of a differentiating male gametophyte and the transition from the program of early genes to the program of late genes. After the two-cell pollen grain stage a decrease in the diversity of transcripts takes place. This phenomenon is linked to terminal differentiation. It is accompanied by the activation of new groups of genes which probably function during pollen grain maturation and later during germination and growth of the pollen tube [37]. Finally, the transcriptome of the mature pollen grain is considerably less complex in comparison to the transcriptome of sporophyte tissue. Pollen specific genes and genes showing a high level of expression constitute a large part of this transcriptome. It seems that the transcripts of these genes play a key role in pollen development and also in its germination into the pollen tube.

In $A$. thaliana the transition between the early and late developmental program of the male gametophyte occurs before the second pollen mitosis. Central elements regulating this process are transcriptional factors. Cluster analysis of transcriptional factors has permitted their division into those undergoing expression: (1) at early stages of pollen development, (2) at a later stage of its development and (3) constitutively. Among 1350 presumed transcription factors in A. thaliana 612 were expressed in maturing pollen grains, among them 542 in the initial stages of its development and 405 at a later period [37]. 49 showed a high level of expression but only 27 were pollen specific [77]. Among early pollen genes transcription factors from such families as: $N A C$, WRKY, TCP, ARF, Aux/IAA, HMG-box and Alfin-like were included [37]. The transition between the two developmental programs is also documented by the expression of genes linked to protein synthesis. Initially they constitute as much as $15 \%$ of the group of genes with the highest expression in pollen grains. During the transition between two genetic programs a decrease in the activity of these genes takes place and completely different genes are turned on [77].

Cluster analysis was used to analyze the transition between the two developmental programs [37]. It allows the analysis of changes in expression levels of a set of genes over time. Clusters containing genes important in pollen tube germination and growth and during the process of fertilization are expressed at a high level in the two-cell and three-cell stage of the pollen grain. 
The transcriptome of the mature pollen grain reflects its preparation for germination and growth of the pollen tube, which is particularly visible in its functional analysis. A low level of transcripts was observed for genes encoding transcriptional factors, housekeeping genes and genes encoding proteins indispensable for translation. An especially high level was found for genes linked to cell wall metabolism, cell signaling, the cytoskeleton and also translation factors. In each of these groups specific genes were identified and understanding their role will increase our knowledge of the mechanisms of pollen tube germination and growth. A high level of expression occurs in the groups of genes whose products are indispensable to the initial stages of pollen tube growth i.e. during the synthesis of the cell membrane and cell wall, exocytosis of its structural components, and in the reception and transmission of signals derived from the pistil. Transcripts of these genes are stored in the mature pollen grain and just after pollination they may undergo translation. In the mature pollen grain in the cytoplasm of the vegetative cell the presence of a large amount of poly(A)mRNA has been demonstrated [86]. Some of these transcripts may be stored in the form of mRNP particles called EPP (ribonucleoprotein particle) [35]. Using inhibitors of transcription and translation in A. thaliana a phenomenon, known since the 1960 's, was confirmed $[36,51]$ - that germination and initial growth of the pollen tube do not depend on de novo RNA synthesis but need a resumption of translation. It appears that not only ready to use transcripts are stored in the male gametophyte but also the protein biosynthesis machinery [35]. Earlier biochemical and physiological experiments had proved that in the mature pollen grain a large pool of tRNA and ribosomes necessary for translation during rapid pollen tube growth are stored [51]. Recent investigations on the A. thaliana pollen grain have confirmed the occurrence of a number of ribosomal proteins (At2g36160, At1g07770, At2g41840, At3g09200, At1g33140, At5g45775, At2g37190, At2g20450) in the cytoplasm [32].

\section{CHARACTERISTICS OF THE POLLEN GRAIN PROTEOME}

Investigations on the pollen proteome of $A$. thaliana have complemented our understanding of the expression of genes in the pollen grain and addressed the question whether translation of transcripts required during germination and growth of the pollen tube takes place during the period of pollen grain maturation or only during its germination [34]. In the mature pollen grain, protein products of genes with a high level of transcription are present at a low level and inversely - the level of proteins encoded by genes with a low level of transcription is high. Proteins present at a high level are believed to be predominantly involved in energy metabolism while those at low levels predominantly in the makeup of the cell structure. In the mature pollen grain a large pool of proteins responsible for energy metabolism has been found (21\%) in comparison to the amount of transcripts 
which encode them (1\%) [55]. An hypothesis was proposed that enzymes are accumulated which are responsible for rapid energy release during pollen tube germination. This is confirmed by investigations performed on Lycopersicon esculentum [72] and Oryza sativa [20] pollen grains. The mature pollen stores proteins which will be necessary for immediate release of energy during pollen tube germination as well as transcripts encoding structural proteins and those involved in cell signaling. These transcripts may already be translated during pollen tube germination. Among proteins identified as pollen specific in the proteome are those predominantly responsible for the structure of the cell and its growth and division [34]. Lilium longiflorum pollen grains subjected to $-20^{\circ} \mathrm{C}$ for 2 months were found to have clearly delayed germination. Analysis of their transcriptome and proteome indicates that this is due to the partial degradation of proteins and mRNA stored in the pollen grain, which may have different stabilities [83]. Actinomycin D (an inhibitor of transcription), considerably inhibited pollen tube germination and growth in pollen grains stored in the cold compared to fresh pollen grains. This indicates the necessity of resuming pollen transcription and replacement of mRNA particles degraded by the action of low temperature.

Proteome analysis has shown that in the pollen grain of all analyzed species the largest pool is made up of proteins responsible for carbohydrate metabolism. These results have also helped in understanding the processes of hydrolysis and metabolism of starch during pollen germination. It seems that the vacuolar acid invertase, whose presence has been demonstrated in pollen grains of A. thaliana [34,55], rice [20] and tomato [72], decomposes sucrose into glucose and fructose. At the next stage fructose is phosphorylated by fructokinase. This hexose phosphate is the substrate for a set of further carbohydrate changes, such as glycolysis and the tricarboxylic acid cycle. Key enzymes of these pathways and the electron transport chain occur in mature pollen grains of all species whose proteomes have been analyzed. Acid invertase may participate in the growth of the plant cell and osmoregulation, which seems to be of critical importance during elongation of the pollen tube. The level of both reverse invertase and fructokinase increases during anther maturation and reaches a maximum at the moment when the pollen grain is mature [2].

Proteome analyses performed so far have shown that over $20 \%$ of proteins occurring in mature pollen grains have two types of isoforms: when the same gene encodes proteins changed as a result of posttranslational modifications or when proteins are encoded by different genes. There are distinctly more isoforms of proteins of the first type, probably serving to diversify the proteins of the haploid genome. Such posttranslational modifications may play an important role during pollen grain development [55,72].

The transcripts and proteins present in mature pollen grains can be divided into the following functional categories: (1) those participating in cell wall structure, (2) those participating in the regulation of transcription and translation, (3) those regulating transmembrane transport, (4) and cell cycle regulators. 


\section{GENES INVOLVED IN CELL WALL SYNTHESIS}

A mature pollen grain is surrounded by sporoderm made up of the external sporopolenin exine and the internal pectin-cellulose intine. Exine is synthesized both in the gametophyte and in the somatic tapetum from phenylpropanoid precursors which together with acylated lipids form sporopolenins. Specific transcription factors are involved in the pathway of synthesis of phenylpropanoid precursors. In the A. thaliana pollen grain transcriptome the most representative group among the transcription factors are factors of the $\mathrm{C}_{3} \mathrm{H}$ type [37]. The diversity of $\mathrm{C}_{3} \mathrm{H}$ gametophyte transcription factors suggests that they play an important role in the synthesis of proteins required for the regulation of chemical interactions between phenylpropanoid precursors [37].

Pollen grain germination requires sporoderm modification whereas for the rapid growth of the pollen tube intensive synthesis of new cell wall with a specific structure is necessary. The internal layer of the pollen tube wall is mainly made up of homogeneous callose (1,3- $\beta$-glucan polymer), whereas the external fibrillar layer is composed of cellulose (1,4- $\beta$-glucan polymer) and pectins (polygalacturonic acid polymers). Thus the presence of a large number of genes responsible for cell wall synthesis and remodeling in the pollen transcriptome is not surprising.

Transcripts of genes involved in sporoderm and pollen tube wall metabolism constitute a large percent, both qualitatively and quantitatively, of the pollen transcriptome of $A$. thaliana. Five out of six of the most abundant mRNA molecules in mature pollen grains encode proteins involved in cell wall metabolism such as polygalacturonases and pectin esterases. Among five families of glucoside hydrolases expressed in the pollen grain GHF1 ( $\beta$-glucosidase), GHF16 (xyloglucan endotransglucosylase), GHF28 (polygalacturonase), GHF35 ( $\beta$ galactosidase) and CHF9 (gluconase/cellulase), are not expressed in sporophyte tissues. Four members of the polygalacturonase family GHF28 are pollen specific. The genes of these polygalacturonases are expressed at a high (At3g07820, At3g07850, At2g23900) or medium (At4g33440) level. Among genes encoding glucosyltransferases, 11 have been identified which are expressed in pollen, six of them showing a high level of expression and are pollen specific. Four of these transcripts belong to the GAF2 family and two of them encode cellulose synthase (At4g11050 and At4g38190) [37]. Analysis of the pollen transcriptome on an ATH1 microarray supplemented this list of transcripts by callase synthase AtGsl2 (At2g13675) and AtCsID1 (presumably cellulose synthase; At2g 33100) [4]. During germination and slowed growth of the pollen tube in A. thaliana gene AtCSLA7 ( $\beta$-glucosyltransferase or cellulose synthase) mutants a number of enzymes belonging to the same GT2 family were found to be involved in the synthesis of the pollen tube cell wall [31]. 
Analysis of the proteome of the mature A. thaliana pollen grain has shown that the level of proteins responsible for cell wall reconstruction is not high in comparison to other functional groups of proteins [34,55]. This indicates that the transcripts encoding them undergo translation only during pollen tube growth.

The wall of the pollen tube tip must be resistant enough to cope with high turgor and at the same time plastic enough to enable inclusion of new membranes and structural materials. Pectins are one of the more important components of the pollen tube cell wall. These compounds are isolated as methylated esters and then deesterified by the enzyme pectin methyl esterase (PME). Free carboxyl groups which arise in this way may cross-bind $\mathrm{Ca}^{2+}$, which reinforces the structure of the cell wall below its growing tip. The effect of giving exogenous PME to pollen tubes growing in vitro is a thickening of the cell wall at the tip and inhibition of its growth [14]. This phenomenon indicates that a strict control of PME activity is an indispensable condition for proper pollen tube growth. In the mature pollen grain proteome of all species analyzed so far $[20,34,55,72]$ both the presence of PME and its inhibitor PMEI, which modifies PME activity post-translationally, have been detected [29]. The PMEI (At4g24640) inhibitor identified in A. thaliana has been considered as pollen specific [34].

In the mature male gametophyte a high level of expression is shown by proteins anchored in the cell membrane by GPI (glycosylphospatidylinositol), called GAP (GPI-anchored proteins). These proteins are involved in the synthesis and reconstruction of the cell wall of the pollen tube, intercellular signaling, adhesion and directional growth. GPI can anchor such proteins as 1,3- $\beta$-glucanases, glycerophosphodiesterases, expansins, classical AG proteins, AG peptides, COBRA and potential GAPEP signal peptides in the membrane [13]. Investigations using microarrays and PCR have shown the presence of the transcripts of 47 genes encoding GAP proteins in A. thaliana pollen grains. In its proteome, 11 proteins linked to the plasma membrane by GPI have been detected [43]. Anchoring of proteins by GPI is the presumed mechanism of directing them to the membrane and allows for polarized localization of proteins involved in signaling [43].

GAP proteins are included in the apical region of the growing pollen tube [43]. As it grows, further away from the tip the GAP proteins are recycled by specialized endosomes. The actin cytoskeleton is responsible for directing proteins anchored by GPI into appropriate parts of the membrane [62]. In A. thaliana sethI and seth 2 mutants which have perturbed biosynthesis of the GPI anchor, an inhibition of germination and pollen tube growth takes place caused by irregularities in the callose wall synthesis [43]. 1,3- $\beta$-glucanase, which probably prevents the deposition of callose at the tip of the pollen tube, can be anchored by GPI in the membrane.

The analysis of the proteome of an A. thaliana pollen grain indicated only the presence of two proteins attached to the cell membrane by a GPI anchor [34]. These are At1g29250, which is specific only for plants, and the GAP protein 
At5g20230 linking and transporting copper ions, which are cofactors of many enzymes among others taking part in ATP synthesis.

In the pollen tube membrane expansin is anchored through GPI and its presence has been noted in both the pollen proteome and transcriptome. This protein disrupts non-covalent bonds between cellulose microfibrills, loosening the structure of the cellulose wall, and allows for its faster growth [43]. It may also be responsible for loosening of the cell wall of the stamen and the pistil transmission tissue during pollen tube penetration [41,74].

Analysis of the pollen transcriptome using microarrays demonstrated the presence of transcripts of a gene encoding protein COBL11 (At4g27110), which is anchored in the membrane through GPI and is a member of the COBRA family. Numerous investigations on $A$. thaliana mutants have demonstrated the participation of COBRA proteins in the regulation of elongation and direction of growth of root cells, probably via an indirect or direct effect on the synthesis of cellulose chains. COB proteins are directed to elongated walls of root cells and recruited into appropriate places as complexes responsible for cellulose synthesis [64]. On this basis COBL11 has been suggested to play a similar role during pollen tube growth [5].

Proteins anchored through GPI may be cleaved from the lipid part of the membrane and function as soluble signal particles [67]. Pollen transcriptome analysis has demonstrated a high level of expression of a gene encoding this type of protein, namely AGP23 (At3g57690). Even though the function of AGP proteins in pollen tubes and the pistil is unknown, it seems interesting that AGP23 encodes the AG peptide 61 amino acids for length which, after cleavage from the lipid part, may act as a soluble signal particle [5].

In mammals, proteins anchored through GPI are essential for sperm-egg adhesion [1]. Mouse oocytes with a knockout of the gene encoding the enzyme participating in the biosynthesis of the GPI anchor are incapable of fusing with the male gamete. Similar mechanisms are suggested to exist during fertilization in angiosperms [59].

\section{CYTOSKELETON}

The cytoskeleton with the secretory apparatus is an effective system in the pollen tube responsible for factors determining the direction of its growth [49]. Specific polarization of actin filament bundles in the pollen [46] is the mechanism for directed cytoplasmic flow - in the submembrane part in the direction of the tip, and in the central part towards its base [33]. The functioning of the actin cytoskeleton is also responsible for the site of construction of the pollen tube tip. Through interaction with myosin, actin filaments may place in an appropriate site and position secretory vesicles participating in the extension of the cell membrane 
and wall and also limit to specific regions of the membrane sites of occurrence of ion channels. The elongation of actin filaments in the vicinity of the tip is part of the force responsible for pushing it forward [80]. Under in vivo conditions the rearrangements of F-actin, which may be induced in response to stimuli derived from transmission tissue of the pistil determine new sites of exocytosis of secretory vesicles which leads to a change in the direction of growth of the pollen tube [49].

Analysis of the transcriptome and proteome of mature A. thaliana pollen grains has demonstrated that both transcripts of genes encoding cytoskeleton proteins and proteins participating in its functioning are present. The level of transcripts of genes encoding cytoskeleton proteins in mature pollen grain is very high. Four out of five actin genes which are expressed in generative tissues belong to the group with the highest level of transcripts [36]. In pollen, transcripts of actin 4 and 12 and the small protein profilin 4, which participates in regulation of actin filament polymerization, have been detected. A gene not previously characterized has also been identified encoding a protein which is also responsible for actin depolymerization (At4g25590). Analysis of the A. thaliana pollen proteome has shown the presence of two pollen specific factors responsible for actin depolymerization [34].

A high level of transcripts was also found for genes encoding motor proteins interacting with the cytoskeleton. In the mature pollen grain the presence of transcripts encoding myosin (AtVIIID and AtXID), which participates in the transport of vesicles along actin filaments, has been observed as well as a transcript encoding a kinesin-like protein (At1g09170), probably involved in movement along microtubules [5].

Analysis of pollen grain proteomes of A. thaliana [56], rice [20] and tomato [72] has confirmed data from other investigations on the presence of such cytoskeleton proteins as actin, tubulin and prolifin in pollen grains.

\section{SIGNALLING}

The pollen tube is considered to be one of the best plant models for analyzing signal transduction. In this cell many signalling pathways have been identified including $\mathrm{Ca}^{2+}$, calmodulin, phosphoinositols, protein kinases, cyclic AMP and GTPases. They form a large and complex network of cell signalling which intercrosses at different levels, such as control of vesicle direction and fusion, and the state of the actin cytoskeleton [49].

Directing the pollen grain and the growth of the pollen tube in a strictly defined direction requires the reception of specific signals sent from pistil tissues. Receptor protein kinases are believed to be responsible for their reception and transduction into the gametophyte. The analysis of the transcriptome of the $A$. thaliana pollen grain has shown a high level of transcripts linked to cell signalling 
and, in particular, receptor kinases. $25 \%$ of genes undergoing selective expression belong to the signal category. Most of them (26 out of 37) presumably encode receptor kinases (receptor-like kinases, RLK). Almost all receptor-like kinases (21 out of 23) are only expressed in the pollen grain and thus are pollen specific [36]. This specificity has been observed not only at the level of particular genes but also at the level of RLK subfamilies. Out of 9 RLK subfamilies expressed in the pollen grain 4 were not expressed in sporophyte tissues. Among them were proline-rich extensin-like receptor kinases, subfamily IX of cytoplasmic RLK, Crinckly4-like and a leucine-repeat rich subfamily VI [36]. RKF1 kinase (At1g29750) of $A$. thaliana [75], similarly as the tomato receptor-like kinase LePRK1-3 [54] and that of maize ZmPRK1 [42], are pollen specific.

In tomato (Lycopersicon esculentum) pollen specific receptor-like kinases bind several different ligands and may participate in the regulation of such processes as hydration and pollen germination and growth of the pollen tube in the transmission pathway of the pistil. In the membrane of mature pollen kinases LePRK21 and LePRK2 form a complex which binds to the pollen ligand (protein) LAT52, leading to phosporylation of kinase LePRK2. This complex is believed to activate the signalling cascade necessary for initiation of pollen germination [85]. After germination the expression of LePRK2 proteins increases strongly and this receptor is believed to participate in further stages of signaling during interaction with pistil tissues. Probably LAT52 is replaced by a ligand present in the extract of the pistil stigma identified as protein LeSTIG1 [76]. Binding of LeSTIG1 causes dissociation of the LePRK1 and LePRK2 complex and LeRPK2 dephosphorylation. It cannot be excluded that during further pollen tube growth in the direction of the ovary protein LeSTIG1 may be replaced by another ligand present in the pistil [76].

In $L$. esculentum KPP has been identified which, interacting with the cytoplasmic domain of LePRK1 and LePRK2 kinases, is phosphorylated by LePRK2 [40]. It is noteworthy that genes similar to KPP are present only in the plants. This may indicate the presence of a unique transduction pathway participating in the apical growth of the pollen tube and rhizome cells of the root [40].

In pollen grains the presence of the transcript of RALF-LIKE peptide 10 (RALFL protein family) has also been detected . Members of this family probably function as intercellular signal molecules binding to different receptor kinases. The RALF-LIKE 10 transcript encodes a 73 amino acid peptide with a potential $\mathrm{N}$ terminal sequence responsible for its export. It is believed this peptide may be a ligand recognized by a leucine residue rich receptor-like kinase present in the pollen grain membrane or in pistil cells [5].

The next element of the signalling pathway through receptor-like kinases, for which transcripts have been demonstrated in A. thaliana pollen grains and pollen tubes, are GTPases of the Rop/Rac type. They work as molecular switches coupling the receptor activation reaction to a cascade of intracellular 
phosphorylations with the participation of MAP kinases. In mature pollen grains transcripts of such GTPases as AtRac1, AtRac6 and Rop1At were present. Rac and Rop belong to the Rho GTPase family and in the pollen tube are probably responsible for the organization of the actin cytoskeleton and pollen tube development, for receiving signals from membrane receptors and transmitting them to proteins and target structures. Rop GTPases play a key role in the fusion of secretory vesicles and endocytosis [49]. In the pollen tube the target molecules for Rop1At are two proteins - RIC3 and RIC4. RIC3, through a secondary transmitter which is $\mathrm{Ca}^{2+}$, leads to actin depolymerization, whereas RIC4 shows an antagonistic activity - actin polymerization [65].

In the pollen grain the transcript of a small GTPase, AtRab2, is present. Rab proteins are the largest family of small GTPases which control the function of specific transport vesicles. RAB2 GTPase is responsible for the transport of vesicles between the endoplastic reticulum and the Golgi apparatus. The occurrence of this protein is characteristic for cells with high secretory activity and in particular for the growing pollen tube. The presence of RAB proteins has been demonstrated in the growing tobacco pollen tube [17]. Using a RAB2-GFP protein construct the fusion protein was found to localize specifically in the Golgi apparatus. It was absent in pollen tubes of plants with a mutant Rab2 gene. The absence of the RAB protein caused perturbations in supplying membranes and proteins to the tip of the pollen tube, which resulted in the inhibition of its growth.

The signal transduction pathway through receptor kinases is known to lead to activation of MAP type protein kinases. In A. thaliana pollen the presence of MAP3K $\gamma$ kinase (At5g66850) transcripts has been demonstrated [49], whereas in tobacco pollen grains the expression of two MAP kinases, $\mathrm{p} 45^{\mathrm{Nt} 4}$ and SIPK, has been demonstrated. These kinases are activated after hydration and are believed to be responsible for phosphorylation of profilin - a protein involved in the regulation of actin polymerization [47].

Experimental evidence has confirmed the important role of the ROP GTPase in the signal pathway during pollen grain germination and pollen tube growth. Both in Arabidopsis and tobacco growing pollen tubes and in root rhizome cells, ROP GTPases are localized in the tip. From pollen grains of an A. thaliana mutant with a permanently active form of Rop1At abnormal, bulbaceous pollen tubes germinated, whereas in a mutant with a permanently inactive form of this GTPase pollen tube growth was rapidly inhibited. The ROP protein is believed to activate phospholipase $\mathrm{C}$ (phosphatidylinositol kinase) which leads to the formation of a secondary signal molecule $\left(\mathrm{IP}_{3}\right)$, which is responsible for $\mathrm{Ca}^{2+}$ release [49]. This would thus be a molecule which in the pollen tube links two different signaling pathways - through receptor-like kinases and phosphatidylinositol.

The participation of the phosphatidylinositol pathway in the directed growth of the pollen tube is still debated [49]. However, in the A. thaliana pollen grain a high level of transcripts of genes involved in this process has been found: 
At2g18180 (phosphatidylinositol/phosphatidylcholine transfer protein) protein transporting phospholipids from the site of their synthesis in the ER and AG to other cellular membranes, At2g43900 (inositol polyphosphate 5'-phosphatase) and At2g31830 (inositol polyphosphate 5'-phosphatase) - enzymes hydrolyzing $\mathrm{IP}_{3}$ and thus terminating this signaling pathway [15] and At2g41210 (phosphatidyloinositol-4-phosphate 5-kinase) - an enzyme taking part in PIP2 synthesis [5]. The phosphatidylinositol signal pathway is based on the production of secondary transmitters, such as $\mathrm{Ca}^{2+}$ ions.

The significance of the precise regulation of the cytosol $\mathrm{Ca}^{2+}$ level in the control of the growth of the pollen tube has been demonstrated by numerous investigations from the 1990's. The maintenance of the so-called tip-to-base $\mathrm{Ca}^{2+}$ gradient is necessary for its correct growth [7]. The decreased $\mathrm{Ca}^{2+}$ level in the subapical region of the pollen tube enables proper functioning of the cytoskeleton while its distinct increase at the tip causes actin filament fragmentation. The vilin protein is responsible for the process of actin filament fragmentation. This protein has the highest activity at the pollen tube tip, i.e. in the cytoplasmic regions with the highest calcium concentration [26]. The $\mathrm{Ca}^{2+}$ sensor is the cytosol protein calmodulin $(\mathrm{CaM})$, after binding calcium ions, activates specific protein kinases leading to a cell response. Analysis of the A. thaliana pollen transcriptome has demonstrated the occurrence of transcripts encoding two putative calmodulins (At4g03290, At4g12860), which were selectively expressed in the gametophyte [5]. Proteome analysis has confirmed the presence in the pollen grain of both calmodulin as well as other $\mathrm{Ca}^{2+}$ binding proteins, such as calreticulin and annexins $[34,55]$. The presence of the transcripts of five calcium-dependent protein kinases: CPK14, -18, -20, -24 and -26 (At2g41860, At4g36070, At2g38910, At2g31500 and At4g 38230) was also observed [5].

Calmodulin present in the pollen tube is the presumed integrator of signals between $\mathrm{Ca}^{2+}$ and such elements of the cytoskeleton as myosin and vilin [49]. The decrease in calmodulin levels on one side of the pollen tube has been shown to decrease secretory activity in this region and cause a change in the direction of its growth [60]. A similar effect on the direction of pollen tube growth is caused by a decrease in cAMP levels. Treatment of pollen tubes with substances increasing cAMP levels (forskolin) or cAMP analogs has been found to cause a transient increase in calmodulin activity [60]. The use of an inhibitor of adenylate synthase causes a decrease in its activity. On this basis the it was suggested that calmodulin links the phosphoinositol signal transduction pathway to the cAMP pathway [60]. 


\section{TRANSCRIPTION}

Analysis of the expression of transcription factors will make it possible to determine whether de novo transcription is required for pollen germination and if it is necessary at later stages of pollen tube growth [6].

Microarray analysis has confirmed that the level of expression of transcription factors and factors responsible for mRNA maturation in the mature pollen grain is low in comparison to other pollen genes. The only exception are MADS genes. Members of the MADS family are involved in the control of developmental processes, such as organogenesis, flowering time, fruit formation and endothelium development [57]. They may play a similar role i.e. control of developmental processes, during pollen grain maturation and pollen tube growth. Of 110 known genes of the MADS block, 79 are present on the Affymetrix ATH1 microarray, 17 genes are expressed in the pollen grain, and 9 of them are at a high level which indicates the high participation of this family in the pollen grain transcriptome. They belong to non-classical genes of the MADS type I block and MIKC, whose role is still unknown. In mature pollen grain transcripts of the MIKC family such as AGL104, AGL66, AGL30, AGL65, and type I AGL29, AGL84, At4g14530 and AGL49 are present [59]. MIKC proteins interact with each other forming five heterodimeric complexes of transcription factors which bind DNA with high specificity in vitro: AGL30/66, AGL 65/66, AGL 94/66, AGL 30/104 and AGL 65/104 [82]. Numerous MIKC protein binding sites in the promoter of many late pollen genes have been found in Arabidopsis thaliana [82]. It has been shown that the lack or small amount of MIKC proteins and their complexes inhibits pollen tube germination in vitro. In the maturing pollen grain the lack of MIKC complexes significantly affected the expression of over 1300 genes, in particular those participating in the main pathways of hormone action, metabolic processes and in posttranslational protein regulation. In maturing pollen grains AtMIKC complexes inhibit the expression of early pollen genes and activate the transcription of genes characteristic of the mature pollen grain [82].

In the Arabidopsis thaliana transcriptome the DUO1 factor has been found, a new member of the subfamily of pollen-specific MYB transcription factors. DUO1 is specifically expressed in the male cell line, in the pollen grain and in particular in the generative cell and sperm cells. A mutation of the duol gene causes a lack of division of the generative cell. This factor is believed to be possibly responsible for the entry of the cell into division due to the activation of cyclin genes [63].

Transcription during germination and growth of the pollen tube is more important than was previously believed. At least one transcript from each family of transcription factors shows expression at a rather high level [5,58]. A transcriptional inhibitor (actinomycin D) was found to affect $A$. thaliana pollen tube growth and germination [37,84]. Resumption of transcriptional activity during 
pollen tube growth has been found in Hyacinthus orientalis [87]. Analysis of the A. thaliana pollen and in vitro grown pollen tube transcriptomes which showed an increase in the number of trancripts during pollen germination [84] appears to confirm that in spite of the presence in the pollen grain of long-lived mRNA, the pollen tube nucleus may be transcriptionally active.

\section{TRANSLATION}

In the pollen grain the pattern of expression of genes encoding translation initiation factors is similar to that occurring in sporophyte tissues, the only exception being PAB proteins (poly(A) binding protein) [36]. In A. thaliana seven of the eight $P A B$ genes are expressed in maturing pollen grain. Three PAB proteins are pollen specific (PAB3, PAB6, PAB7), whereas PAB5 is selectively expressed in pollen at a high level. $P A B 6$ and $P A B 7$ belong to late basal genes of the translation initiation [37]. The role of $\mathrm{PAB}$ proteins is twofold: they participate in translation initiation and they affect poly(A)mRNA stability [48]. The presence of a poly(A) to which $\mathrm{PAB}$ proteins bind is not required for translation, although transcripts with this sequence give much better yields. PAB proteins interact with the translation initiation factor eIF4G. At the same time their interaction with the cap binding protein eIF4E causes mRNA circularization, which facilitates ribosome recycling [8]. This circularization prevents deadenylation by poly(A)ribonucleases (PARN). Deadenylation is the first step leading to transcript degradation [30]. PAB proteins may also be involved in the regulation of the halflife of mRNA molecules containing special sequences determining their stability, such as AU-rich elements (ARE) and mCRD [30]. This is especially important for pollen grains in which a large pool of long-lived mRNA is stored and pollen tube germination and growth are linked to global initiation of transcription independent protein synthesis. Because of this the timing of translation initiation and the mRNA half-life must be strictly controlled.

Investigations in A. thaliana [55], rice [20] and tomato [72] have shown that over $9 \%$ of the pollen grain proteome participates in protein maturation and of this $75 \%$ participates in determining their destination (e.g. chaperonins, cyclophilins). This agrees with the hypothesis that the mature pollen grain contains a prepared machinery indispensable for synthesis and maturation of proteins directly after its hydration [55]. 


\section{MEMBRANE TRANSPORT}

Numerous experiments have demonstrated the decisive importance for pollen tube growth of gradients of ions such as $\mathrm{Ca}^{2+}, \mathrm{Cl}^{-}, \mathrm{K}^{+}$and $\mathrm{H}^{+}$. For a long time the molecular identity of transporters responsible for maintenance was not known. The analysis of the pollen grain transcriptome by microarray analysis permitted the identification of genes encoding proteins participating in ion transport. In the A. thaliana genome 1269 genes were discovered encoding transporters with 757 transcripts found in the transcriptome of the male gametophyte. $16 \%$ of that number, or 124 genes, including AHA6, CNGC18, TIP1.3 and CHXO8, are pollen specific or expressed at a high level [10].

Pollen tube growth occurs in a pulsating fashion, accompanied by oscillatory changes in concentrations of $\mathrm{Ca}^{2+}, \mathrm{Cl}^{-}, \mathrm{K}^{+}$and protons. Ion and metabolite transport in the pollen grain is necessary not only for the uptake of nutrients, maintenance of metabolism and energy production during growth but also for cell signaling, development and resistance to stress [27]. The signaling network modulates pumps, carriers and channels in time and space so as to coordinate ion influx, their gradient and oscillations. The level of transcripts of genes encoding known and putative membrane transporters is much higher in mature pollen grain than in the microspore. This underlines their importance during pollen tube growth [10].

Calcium channels, such as CNGC and ACA calcium pumps (autoinhibited $\mathrm{Ca}^{2+}$-pumping ATPases), presumably play an important role in the maintenance of the $\mathrm{Ca}^{2+}$ gradient and its oscillations[10]. The Arabidopsis genome encodes 14 of these pumps, 10 of them controlled by $\mathrm{Ca}^{2+} /$ calmodulin. ACA10 and ACA13 genes are expressed in early stages of pollen grain maturation [37]. ACA2, ACA7 and $A C A 9$ are among late pollen genes. The ACA9 gene is expressed in the pollen grain at a very high level and its product is localized in the plasma membrane [68]. The calcium pump encoded by the ACA9 gene is believed to possibly participate in the growing pollen tube in maintenance of $\mathrm{Ca}^{2+}$ homeostasis, in the formation of calcium oscillations at the tip and also in preventing an increase in the level of these ions to a cytotoxic level by pumping $\mathrm{Ca}^{2+}$ ions taken up by calcium channels outside the cell. Homozygous mutants of the aca9 gene (Table 2) had decreased fertility, the pollen grains germinated poorly and pollen tube growth was inhibited [68].

Another ion transporter whose transcripts have been found in A. thaliana pollen grains is the MIA protein (At5g23630), functioning as an $\mathrm{P}_{5}$ ATPase [38]. Mutations in the MIA gene cause a lack of separation of tetrads into individual microspores, which remain surrounded by an electron dense wall. The microspore cell membrane often detaches from the wall, probably due to perturbed cation metabolism and problems with maintaining turgor. Microarray analysis in such mutants demonstrated the lack of expression of genes involved in the secretory 
pathway, cell wall metabolism and cell signalling. The MIA protein was present in the endoplasmic reticulum and in small vesicles of reticular origin and is presumed to participate in control of the secretory pathway. It probably affects protein biogenesis and transport by regulation of ion homeostasis in secretory pathway compartments [38].

$\mathrm{H}^{+}$pumps (e.g. AHA3, AHA6, AHA8 and AHA9) probably participate in maintaining proton oscillation in the growing pollen tube, as well as $\mathrm{H}^{+}$ transporters (e.g. CHX) and anion channels (e.g. CLC), which change the membrane potential and $\mathrm{pH}[10]$. The $A H A 3$ gene is transcribed at a high level during the early stages of development of the male gametophyte. On the other hand AHA6, AHA 8 and AHA9 genes belong to specific late pollen genes. AHA genes encode $\mathrm{H}^{+}$-ATPases of the $\mathrm{P}$ type. The proton gradient is used for nutrient uptake. The participation of type $\mathrm{P} \mathrm{H}^{+}$-ATPase in deposition of components of the cell wall and in intracellular signalling also cannot be excluded [61]. In the observed aha3 mutants of Arabidopsis thaliana the male gametophyte died in the early stages of its development (Table 2).

In the mature pollen grain a high level of transcripts encoding the $\mathrm{K}^{+}$SPIK (AKT6) and SKOR channels are present [10]. It seems that for the growth of the pollen tube the $\mathrm{K}^{+}$AKT6 channel, whose gene undergoes specific transcription in the pollen grain, is important. Potassium ions have been shown to be responsible for cell elongation and transduction of various signals [16], and with other osmoprotectants are responsible for turgor maintenance [53]. In the growing pollen tube the potential-dependent SPIK channel is responsible for influx of $\mathrm{K}^{+}$ions. Analysis of the spik-1 mutant (Table 2) has shown that the growth of pollen tubes in vitro was inhibited in spite of the presence of physiological amounts of $\mathrm{K}^{+}$in the medium. Under in vivo conditions the mutation made it impossible for them to compete in the pistil with wild type pollen tubes [53]. The SKOR channel is permeable both to monovalent cations such as $\mathrm{K}^{+}$, and divalent $\mathrm{Ca}^{2+}$ ions. Its activity is regulated by cytoplasmic $\mathrm{pH}-\mathrm{a}$ decrease in $\mathrm{pH}$ causes an inhibition of its permeablity [4].

Other channels important for pollen tube growth are ion channels regulated by cyclic nucleotides e.g. AtCNGC16 (At3g480110). They are probably involved in the control of the cytosol $\mathrm{Ca}^{2+}$ level. An increase in the cAMP or cGMP level causes an influx of $\mathrm{Ca}^{2+}$, resulting in an increase in calcium levels in the pollen tube cytoplasm. AtCNGC channels are suggested to be regulated both by cyclic nucleotides and calmodulin, as they have binding sites for both these molecules. As cAMP is known to have an effect on pollen tube growth and orientation, the AtCNGC16 channel is believed to play the role of a linker between increasing cAMP levels and $\mathrm{Ca}^{2+}[5,10]$.

Germination and, in particular, pollen tube growth require the supply of a large amount of sugars. In A. thaliana several genes have been found to be expressed belonging to the STP and SUC families whose protein products can participate in this process. Proteins belonging to the STP family act as 
$\mathrm{H}^{+}$/monosugar transporters. In maturing pollen grain transcripts of 5 monosaccharide transporters have been detected undergoing differentiated regulation during its development. The AtSTP2 gene is transcribed at early stages of pollen grain maturation. Transcripts of AtSTP9, 4, 6 and 11 genes are present in mature pollen grains but their protein products only appear after germination of the pollen tube [70,71]. The level of transcripts of AtSTP genes in mature pollen is very high, and AtSTP11 (Table 2) is among the 50 genes with the highest level of expression in hydrated pollen grains [5] and is predominantly responsible for providing monosaccharides to the growing pollen tube.

Unspecific pollen genes undergoing selective expression in the pollen grain in relation to other members of the same family also play an important role during pollen tube growth. An example of these types of proteins is the $\mathrm{H}^{+} /$saccharose symporter (At1g71880). It is the only member of the SUC family expressed at a high level in the three cell pollen grain. hap3 mutants (of the SUClgene) germinate but the pollen tubes are short and do not grow through the pistil tissues. This suggests an important role for SUCl (Table 2) in saccharose uptake during pollen tube growth [39].

In A. thaliana pollen transcripts of $\mathrm{ABC}$ transporters $\mathrm{ABC}$, AGAP (amino acids), oligopeptides and nitro groups (OPT and POT) have also been detected [10].

TABLE 2. Functional characterization of proteins involved in membrane transport in maturing $A$. thaliana pollen grain (after [43], modified).

\begin{tabular}{|c|c|c|c|}
\hline ACA9 & Pollen tube membrane & $\begin{array}{c}\mathrm{Ca}^{2+} \text { pump important for } \\
\text { maintaining calcium } \\
\text { homeostasis }\end{array}$ & [68] \\
\hline AHA3 & $\begin{array}{c}\text { Late microspore and } \\
\text { cell undergoing mitosis }\end{array}$ & $\begin{array}{c}\mathrm{H}^{2+} \text { pump generating the } \\
\text { force for nutrient uptake }\end{array}$ & {$[61]$} \\
\hline SPIK & Grain and pollen tube & $\begin{array}{c}\text { Uptake of } \mathrm{K}^{+} \text {ions } \\
\text { required for pollen tube } \\
\text { growth }\end{array}$ & [53] \\
\hline STP11 & $\begin{array}{c}\text { Protein occurring } \\
\text { exclusively in the } \\
\text { pollen tube }\end{array}$ & $\begin{array}{c}\text { Providing } \\
\text { monosacharides for the } \\
\text { growing pollen tube }\end{array}$ & {$[70]$} \\
\hline SUC1 & Pollen tube membrane & $\begin{array}{c}\text { Sucrose uptake by the } \\
\text { growing pollen tube }\end{array}$ & {$[73]$} \\
\hline
\end{tabular}




\section{CELL CYCLE}

In most of the analyzed species the nucleus of the vegetative cell is arrested in phase $\mathrm{G}_{1}$ of the cell cycle. Analysis of ATH1 microarrays, which contain probes for about $90 \%$ of the basic cell cycle genes of A. thaliana, has permitted a hypothetical explanation of the mechanism of cell cycle arrest of the mature pollen grain [58]. In the pollen grain transcriptome the mRNA of transcription factor E2F-DP which is necessary for transition of the cell cycle is completely absent, as are cyclins of the D3 type, including cyclin CYCD3;1 promoting entry into $\mathrm{S}$ phase [21]. Cyclin $\mathrm{D}$ in somatic cells forms a complex with cyclin-dependent type A kinase (CDKA), which phosphorylates the retinoblastoma $(\mathrm{Rb})$ protein. The phosphorylated form of $\mathrm{Rb}$ dissociates from the E2F/DP1 complex, which allows the transcription of genes required for the phase G1 to $S$ transition [79]. In the case of absence of cyclin D, transcription factor E2F forms a complex with the unphosphorylated form of $\mathrm{Rb}$. This complex, by binding to appropriate genes, inhibits their expression.

In the mature pollen grain a high level of transcripts of DEL proteins (DPE2F-like) was observed; they are similar to E2F proteins, but do not have a domain responsible for transcription activation. They may bind to E2F binding sites. However, this binding does not activate the transcription of appropriate genes [50]. In the A. thaliana pollen grain a high level of expression of CKS1 and CKS2 proteins, which are known to interact with CDK and cause cell cycle arrest, was found [58].

The pollen grain generative cell undergoes a full cell cycle as it divides mitotically into two sperm cells. The cell cycle of sperm cells is very poorly known. As in other sexually reproducing organisms, they may remain in phase $\mathrm{G}_{1}$ until fertilization. Nuclei of sperm cells of A. thaliana during pollen shedding are already in phase $S$ and just before fertilization reach phase $G_{2}$ [28]. This appears to concur with the results of investigations of the transcriptome of mature pollen grains of A. thaliana where transcripts of the large vegetative cell predominate but transcripts of two small sperm cells are also present. In the pollen grain primarily transcripts characteristic for the $\mathrm{G}_{2}$ to $\mathrm{M}$ cell phase transition have been detected CDKA/B, CYCA, CYCB, CDKD, CYCH. Some of them e.g. CYCA2;1, CYCB3;1 [5] and CYCA1;2 occur at a high level [58]. The AtMYB3R-4 transcript has been detected whose closest homologues are tobacco genes NtmybAl and NtmybA2. Protein products of these genes are activator elements of plant cyclin type $B$ promoters which accompany the $\mathrm{G}_{2} / \mathrm{M}$ transition [3]. In the pollen grain cyclin-cyclin dependent kinase complexes responsible for entry into mitosis are probably maintained in an inactive form (pre-MPF). Transcripts of the WEE1 gene, encoding a kinase maintaining the so-called pre-MPF inhibiting phosphorylation have been found. A very low level of transcription was found for the CDC25 phosphatase gene, whose protein product could activate the cyclin-kinase complex. 
Sperm cells may be a source of transcripts or proteins responsible for the entry of the zygote into mitosis [58]. Investigations in Zea mays have shown, however, that just after fertilization the level of transcripts of genes whose products participate in replication increases rapidly [22], before the first zygote division regulatory genes of the cell cycle are transcribed de novo [66].

During the analysis of the mature A. thaliana pollen transcriptome no transcripts involved in the small RNA pathway were found. If this is confirmed by functional analysis, the vegetative cell of the pollen grain will be the first known structure not having a posttranscriptional silencing mechanism $[6,58]$.

\section{GENERATIVE CELL AND SPERM CELL TRANSCRIPTOMES}

Analysis of the transcriptome of the generative cell of Lilium longiflorum by means of EST tags has demonstrated that most of the transcriptome is made up of genes involved in DNA repair, activation of cyclins and ubiquitination [56]. At the present stage of investigation it appears that no other plant cell shows such a high degree of specificity of transcripts as the generative cell. A similarly high level of specificity is observed in mouse spermatogenic cells and in Drosophila testes [56].

The FACS method made it possible to isolate A. thaliana sperm cells formed after division of the generative cell and to perform transcriptome analysis on an ATH1 microarray [12]. The highest level of expression was in DNA metabolism (in particular replication and repair), programmed protein destruction by ubiquitination, and the cell cycle. The process of protein degradation by ubiquitination plays an important role during mammalian spermatogenesis in replacing histones by protamines and in other key processes of gametogenesis and fertilization [12]. In plants, the process of exchanging histones for protamines during spermatogenesis has been observed in some species of algae [59].

In the transcriptome of the A. thaliana sperm cell transcription factors were found to be present. These are three factors of the Dof type (At3g47500, At5g39660, At5g62430) [12], probably binding pollen specific promoters AtGEXI and AtGEX2 [25]. The highest level among transcription factors is found for MYB factors. Scarecrow factors belonging to the GRAS family are much less common [11]. Their role in sperm cells remains unknown. However, in cells of the root meristem in A. thaliana they participate in asymmetric divisions and the formation of a radial differentiation pattern [32].

Genes with a high level of expression in sperm cells probably play an important role in the development of male gametes and fertilization. Among these genes can be included genes encoding protein (At1g23210) belonging to the family of glycosyl hydrolases. In mammals glycosyl hydrolase PH-20 is localized in the 
acrosomal membrane, where it plays an important role during sperm adhesion to the zona pellucida of the egg cell [44]. Before fertilization mammalian sperm undergo a capacitation process based on intracellular alkalization and change in membrane potential. It occurs through the influx of $\mathrm{Ca}^{2+}$ ions into the cell and the efflux of $\mathrm{K}^{+}$ions from the cell. A process similar to sperm capacitation is suggested to occur in male plant gametes. In Arabidopsis thaliana sperm cells a high level of AtTPK2 (KCO2) gene is present and its product is responsible for $\mathrm{K}^{+}$homeostasis [12]. Other channel proteins expressed at a higher level in sperm cells than in the pollen grain are probably responsible for maintaining turgor (MSL2\At5g10490, MSL3\At1g58200) [12].

In sperm cells a signalling system also appears to be active even though some complicated signal transduction cascades appear to be simplified and specific. Genes encoding proteins which participate in signalling were found to have limited expression, e.g. only a few members of the lectin receptor kinase family are expressed, one auxin transmitter and one representative of the MAPKK3 kinase family [12]. Genes encoding MAPKKK19\At3g50310 and MAPKKK20\At5g40440 kinases are expressed at a very high level, and thus are specific for sperm cells.

One of the most important mechanisms responsible for the regulation of gene expression is chromatin methylation. The level of expression of a gene depends on the degree of DNA methylation in the promoter sequence, the higher it is the lower the expression of a given gene. In Eukaryota there are two types of methylation - symmetrical CG or CNG and asymmetrical (non-CG). Methylation controls important processes linked with development of the organism [52]. A change in the methylation is known to occur during early stages of mammalian development.

The analysis of the transcriptome of sperm cells in A. thaliana has shown the presence of transcripts of genes responsible for epigenetic control of the genome (Table 3). Among them the highest level of expression was found for: AGO9, DDM1, DRB4, MET1 and SUVH5 [12]. They are responsible for RdDM DNA methylation controlled by siRNA [81]. However, the absence of part of the transcripts which participate in the siRNA pathway e.g. CMT3 and CL3, may indicate that it has a different course in sperm cells [12]. Not detecting transcripts of the siRNA pathway in the transcriptome of whole pollen grains could be the effect of "dilution" due to their very low levels in comparison to transcripts characteristic for the vegetative cell [58]. In this situation sperm transcripts can be treated as background by the software for reading the microarrays.

The Morpheus' 1 (MOM1) molecule is probably also involved in the epigenetic control of the sperm cell genome and is responsible for silencing of highly repetitive sequences independent of DNA methylation [78].

The highest level of expression in sperm cells of A. thaliana was found for the At3g62230 gene encoding an F-box protein. In the transcriptome other F-box group mRNAs have been found. The C-terminus of F-box proteins contains 
domains responsible for the specificity of substrate binding which is later the target for degradation by the SCF ubiquitin-ligase complex. Such a large number and diversity of transcripts responsible for protein degradation is indispensable for degrading molecules required during early stages of microgametogenesis e.g. cell cycle regulators [12]. It also seems that transcripts or proteins stored in sperm cells can be transferred to the egg and central cells and after fertilization may play an important role in early embryonic development.

TABLE 3. Genes involved in RdDM whose expression was found in A. thaliana sperm cells (after $[12,53])$.

\begin{tabular}{|c|c|c|c|}
\hline Gene & AGI number & Activity & Role \\
\hline NRDP1b & At2g40030 & Subunit of polymerase IVb & de novo DNA methylation \\
\hline DDM1 & At5g66750 & $\begin{array}{c}\text { SWI2/SNF2- chromatin } \\
\text { remodeling factor }\end{array}$ & $\begin{array}{c}\text { Maintenance of CG } \\
\text { methylation }\end{array}$ \\
\hline HEN1 & At4g20910 & RNA methylase & $\begin{array}{c}\text { Methylation of 21-24 nt } \\
\text { siRNA }\end{array}$ \\
\hline MET1 & At5g49160 & DNA methyltransferase & $\begin{array}{c}\text { Maintenance of CG } \\
\text { methylation }\end{array}$ \\
\hline SUVH5 & At2g35160 & $\begin{array}{c}\text { Methyltransferase of histone H3 } \\
\text { lysine 9 }\end{array}$ & $\begin{array}{c}\text { Histone methylation, } \\
\text { maintenance of non-CG } \\
\text { methylation by CMT3 [23] }\end{array}$ \\
\hline
\end{tabular}

\section{SUMMARY}

The results of investigations on the pollen transcriptome and proteome are indubitably a great step forward in understanding the genetic mechanisms of development and differentiation of the male gametophyte in angiosperms. Analysis of the pollen proteome of such species as Arabidopsis or Oryza to a large extent confirms and supplements the results of investigations performed using microarrays. The results not only considerably increases our current knowledge of the molecular bases of sexual reproduction in plants but also raises a number of new questions and problems which plant embryologists will need to address. For example, apparent absence in the vegetative pollen grain cell of A. thaliana of the activity of genes linked to the pathway of small RNAs responsible for gene silencing or the selective expression of specific transcription factors of the MADS block family. It is possible that the regulation of gene expression in cells of the male gametophyte of angiosperms takes place in a different way to that in vegetative tissues. Certainly the next decade of investigations on the pollen transcriptome and proteome will hopefully provide answers the many of the current questions. 


\section{REFERENCES}

[1] ALFIERI JA, MARTIN AD, TAKEDA J, KONDOH G, MYLES DG, PRIMAKOFF P. Infertility in female mice with an oocyte-specific knock-out of GPI-anchored proteins. $J$ Cell Sci 2003; 116: $2149-2155$.

[2] ALVES-FERREIRA M, WELLMER F, BANHARA A, KUMAR V, RIECHMANN JL, MEYEROWITZ EM. Global expression profiling applied to the analysis of Arabidopsis stamen development. Plant Physiol 2007; 145: 745-762.

[3] ARAKI S, ITO M, SOYANO T, NISHIHAMA R, MACHIDA Y. Mitotic cyclins stimulate the activity of c-myb-like factors for transactivation of $\mathrm{G}_{2} / \mathrm{M}$ phase-specific genes in tobacco. $J$ Biol Chem 2004; 279: 32979-32988.

[4] BECKER D, GEIGER D, DUNKEL M, ROLLER A, BERTL A, LATZ A, CARPANETO A, DIETRICH P, ROELFSEMA MRG, VOELKER C, SCHMIDT D, MUELLER-ROEBER B, CZEMPIŃSKI K, HEDRICH R. AtTPK4, an Arabidopsis tandem-pore $\mathrm{K}^{+}$channel, poised to control the pollen membrane volatage in $\mathrm{pH}-$ and $\mathrm{Ca}^{2+}$-dependent manner. Proc Natl Acad Sci USA 2004; 101: 15621-15626

[5] BECKER JD, BOAVIDA LC, CARNEIRO J, HAURY M, FEIJÓ JA. Transcriptional profiling of Arabidopsis tissues reveals the unique characteristic of the pollen transcriptome. Plant Physiol 2003; 133: 713-725.

[6] BECKER JD, FEIJÓ JA. How many genes are needed to make pollen tube transcriptomics. Ann Bot 2007; 100: 1117-1123.

[7] BEDNARSKA E, LENARTOWSKA M. Rola wapniowego systemu przekazywania sygnałów w regulacji wzrostu łagiewek pyłkowych. Post Biol Kom 2000; 27: 467-479.

[8] BELOSTOTSKY DA. Unexpected complexity of poly(A)-binding protein gene families in flowering plants: three conserved lineages that are at least 200 million years old and possible autoand cross-regulation. Genetics 2003; 163: 311-319.

[9] BOAVIDA LC, BECKER JD, FEIJÓ JA. The making of gametes in higher plants. Int J Dev Biol 2005; 49: 595-614.

[10] BOCK KW, HONYS D, WARD JM, PADMANABAM S, NAWROCKI EP, HIRSCHI KD, TWELL D, SZE H. Integrating membrane transport with male gametophyte development and. function through transcriptomics. Plant Physiol 2006; 140: 1151-1168.

[11] BOLLE C. The role of GRAS proteins in plant signal transduction and development. Planta 2004 218: 683-692.

[12] BORGES F, GOMES G, GARDNER R, MORENO N, McCORMICK S, FEIJÓ JA, BECKER JD Comparative transcriptomics of Arabidopsis sperm cells. Plant Physiol 2008; 148: 1168-1181.

[13] BORNER GH, SHERRIER DJ, STEVENS TJ, ARKIN IT, DUPREE P. Prediction of glycosylphosphatidylinositol-anchored proteins in Arabidopsis. A genomic analysis. Plant Physiol 2002; 129: 486-499.

[14] BOSCH M, CHEUNG AY, HEPLER PK. Pectin methylesterase, a regulator of pollen tube growth. Plant Physiol 2005; 138: 1334-1346.

[15] CARLAND FM, NELSON T. Cotyledon vascular pattern2-mediated inositol $(1,4,5)$ triphosphate signal transduction is essential for closed venation patterns of Arabidopsis foliar organs. Plant Cell 2004; 16: 1263-1275.

[16] CHÉREL I. Regulation of $\mathrm{K}^{+}$channel activities in plants: from physiological to molecular aspects. $J$ Exp Bot 2004; 55: 337-351.

[17] CHEUNG AY, CHEN CY, GLAVEN RH, DE GRAAF BH, VIDALI L, HEPLER PK, WU HM. Rab2 GTPase regulates vesicle trafficking between the endoplasmic reticulum and the Golgi bodies and is important to pollen tube growth. Plant Cell 2002; 14: 945-962.

[18] CHEVALIER F, MARTIN O, ROFIDAL V, DEVAUCHELLE AD, BARTEAU S, SOMMERER N, ROSSIGNOL M. Proteomic investigation of natural variation between - Arabidopsis ecotypes Proteomics 2004; 4: 1372-1381.

[19] DA COSTA-NUNES JA, GROSSNIKLAUS U. Unveiling the gene-expression profile of pollen. Genome Biol 2003; 5: 205. 
[20] DAI S, CHEN T, CHONG K, XUE Y, LIU S, WANG T. Proteomics identification of differentially expressed proteins associated with pollen germination and tube growth reveals characteristics of germinated Oryza sativa pollen. Mol Cell Proteomics 2007; 6: 207-230.

[21] DEWITTE W, MURRAY JA. The plant cell cycle. Annи Rev Plant Biol 2003; 54: 235-264.

[22] DRESSELHAUS T, SRILUNCHANG KO, LELJAK-LEVANIC D, SCHREIBER DN, GARG P The fertilization induced-DNA replication factor MCM6 of maize shuttles between cytoplasm and nucleus, and is essential for plant growth and development. Plant Physiol 2006; 140: 512-527.

[23] EBBS ML, BENDER J. Locus-specific control of DNA methylation by the Arabidopsis SUVH5 histone methyltransferase. Plant Cell 2006; 18: 1166-1176.

[24] ENGEL ML, CHABOUD A, DUMAS C, McCORMICK S. Spperm cellls of Ze- Zea mays have have a complex complement of mRNAs. Plant J 2003; 34: 697-707.

[25] ENGEL ML, HOLMES-DAVIS R, McCORMICK S. Green sperm. Identification of male gamete promoters in Arabidopsis. Plant Physiol 2005; 138: 2124-2133.

[26] FAN X, HOU J, CHEN X, CHAUDHRY F, STAIGER CJ, REN H. Identification and characterization of $\mathrm{Ca}^{2+}$-dependent actin filament-severing protein from lily pollen. Plant Physiol 2004; 136: 3979-3989.

[27] FEIJÓ JA, SAINHAS J, HOLDAWAY-CLARKE T, CORDEIRO MS, KUNKEL JG, HEPLER PK. Cellular oscillations and the regulation of growth: the pollen tube paradigm. Bioessays 2001; 23: 86-94.

[28] FRIEDMAN WE. Expression of the cell cycle in sperm of Arabidopsis: implications for understanding patterns of gametogenesis and fertilization in plants and other eukaryotes. Development 1999; 126: 1065-1075.

[29] GIOVANE A, SERVILLO L, BALESTRIERI C, RAIOLA A, D’AVINO R, TAMBURRINI M, CIARDIELLO MA, CAMARDELLA L. Pectin methylesterase inhibitor. Biochim Biophys Acta 2004; 1696: 245-252.

[30] GORGONI B, GRAY NK. The roles of cytoplasmic poly(A)-binding proteins in regulating gene expression: a developmental perspective. Brief Funct Genomic Proteomic 2004; 3: 125-141.

[31] GOUBET F, MISRAHI A, PARK SK, ZHANG Z, TWELL D, DUPREE P. AtCSLA7, a cellulose synthase-like putative glycosyltransferase, is important for pollen tube growth and embryogenesis in Arabidopsis. Plant Physiol 2003; 131: 547-557.

[32] HEIDSTRA R, WELCH D, SCHERES B. Mosaic analyses using marked activation and deletion clones dissect Arabidopsis SCARECROW action in asymmetric cell division. Genes Dev 2004; 18 : 1964-1969

[33] HEPLER PK, VIDALI L, CHEUNG AY. Polarized cell growth in higher plants. Annu Rev Cell Dev Biol 2001; 17: 159-187.

[34] HOLMES-DAVIS R, TANAKA CK, VENSEL WH, HURKMAN WJ, McCORMICK S. Proteome mapping of mature pollen of Arabidopsis thaliana. Proteomics 2005; 5: 4864-4884.

[35] HONYS D, COMBE JP, TWELL D, CAPKOVÁ V. The translationally repressed pollen-specific ntp303 mRNA is stored in non-polysomal mRNPs during maturation. Sex Plant Reprod 2000; 13: 135-144.

[36] HONYS D, TWELL D. Comparative analysis of the Arabidopsis pollen transcriptome. Plant Physiol 2003; 132: 640-652.

[37] HONYS D, TWELL D. Transcriptome analysis of haploid male gametophyte development in Arabidopsis. Genome Biol 2004; 5: R85.

[38] JAKOBSEN MK, POULSEN LR, SCHULZ A, FLEURAT-LESSARD P, MØLLER A, HUSTED S, SCHIØTT M, AMTMANN A, PALMGREN MG. Pollen development and fertilization in Arabidopsis is dependent on the male gametogenesis impaired anthers gene encoding a type $\mathrm{V}$ Ptype ATP-ase. Genes Dev 2005; 19: 2757-2769.

[39] JOHNSON MA, VON BESSER K, ZHOU Q, SMITH E, AUX G, PATTON D, LEVIN JZ, PREUSS D. Arabidopsis hapless mutations define essential gametophytic functions. Genetics 2004; 168: 971-982.

[40] KAOTHIEN P, OK SH, SHUAI B, WENGIER D, COTTER R, KELLEY D, KIRIAKOPOLOS S, MUSCHIETTI J, McCORMICK S. Kinase partner protein interacts with the LePRK1 and LePRK2 receptor kinases and plays a role in polarized pollen tube growth. Plant J 2005; 42: 492-503. 
[41] KERIM T, IMIN N, WEINMAN JJ, ROLFE BG. Proteome analysis of male gametophyte development in rice anthers. Proteomics 2003; 3: 738-751.

[42] KIM HU, COTTER R, JOHNSON S, SENDA M, DODDS P, KULIKAUSKAS R, TANG W, EZCURRA I, HERZMARK P, McCORMICK S. New pollen-specific receptor kinases identified in tomato maize and Arabidopsis: the tomato kinases show overlapping but distinct localization patterns on pollen tubes. Plant Mol Biol 2002: 50: 1-16.

[43] LALANNE E, HONYS D, JOHNSON A, BORNER GH, LILLEY KS, DUPREE P, GROSSNIKLAUS N, TWELL D. SETH1 and SETH2, two components of the glycosylphosphatidylinositol anchor biosynthetic pathway, are required for pollen germination and tube growth in Arabodopsis. Plant Cell 2004; 16: 229-240.

[44] LATHROP WF, CARMICHAEL PE, MYLES DG, PRIMAKOFF P. cDNA cloning reveals the molecular structure of sperm surface protein, $\mathrm{PH}-20$, involved in sperm-egg adhesion and the wide distribution of its gene among mammals. J Cell Biol 1990; 111: 2939-2949.

[45] LEE JY, LEE DH. Use of serial analysis of gene expression technology to reveal changes in gene. expression in Arabidopsis pollen undergoing cold stress. Plant Physiol 2003; 132: 517-529.

[46] LENARTOWSKA M, MICHALSKA A. Actin filament organization and polarity in pollen tubes revealed by myosin II subfragment 1 decoration. Planta 2008; 228: 891-896.

[47] LIMMONGKON A, GIULIANI C, VALENTA R, MITTERMANN I, HEBERLE-BORS E, WILSON C. MAP kinase phosphorylation of plant profilin. Biochem Biophys Res Commun 2004; 324: 382-386.

[48] LUO K, DENG W, XU S, PEI Y. Functional analysis of the Arabidopsis thaliana poly(A)binding protein PAB5 gene promoter in Nicotiana tabacum. Plant Cell Rep 2008; 27: 1811-1819.

[49] MALHÓ R, LIU Q, MONTEIRO D, RATO C, CAMACHO L, DINIS A. Signalling pathways in pollen germination and tube growth. Protoplasma 2006; 228: 21-30.

[50] MARICONTI L, PELLEGRINI B, CANTONI R, STEVENS R, BERGOUNIOUX C, CELLA R, ALBANI D. The E2F family of transcription factors from Arabidopsis thaliana. Novel and conserved components of the retinoblastoma/E2F pathway in plants. J Biol Chem 2002; 277: 9911 9919.

[51] MASCARENHAS JP. The male gametophyte of flowering plants. Plant Cell 1989; 1: 657-664.

[52] MATZKE M, KANNO T, HUETTEL B, DAXINGER L, MATZKE AJ. Targets of RNA-directed. DNA methylation. Curr Opin Plant Biol 2007; 10: 512-519.

[53] MOULINE K, VÉRY AA, GAYMARD F, BOUCHEREZ J, PILOT G, DEVIC M, BOUCHEZ D, THIBAUD JB, SENTENAC H. Pollen tube development and competitive ability are impaired by disruption of a Shaker $\mathrm{K}^{+}$channel in Arabidopsis. Genes Dev 2002; 16: 339-350.

[54] MUSCHIETTI J, EYAL Y, MCCORMICK S. Pollen tube localization implies a role in pollenpistil interactions for the tomato receptor-like protein kinases LePRK1 and LePRK2. Plant Cell 1998; 10: 319-330.

[55] NOIR S, BRÄUTIGAM A, COLBY T, SCHMIDT J, PANSTRUGA R. A reference map of the Arabidopsis thaliana mature pollen proteome. Biochem Biophys Res Commun 2005; 337: 1257 1266.

[56] OKADA T, SINGH MB, BHALLA PL. Transcriptome profiling of Lilium longiflorum generative. cells by cDNA microarray. Plant Cell Rep 2007; 26: 1045-1052.

[57] PARENICOVA L, DE FOLTER S, KIEFFER M, HORNER DS, FAVALLI C, BUSSCHER J, COOK HE, INGRAM RM, KATER MM, DAVIES B, ANGENENT GC, COLOMBO L. Molecular and phylogenetic analyses of the complete MADS-box transcription factor family in. Arabidopsis: new openings to the MADS world. Plant Cell 2003; 15: 1538-1551.

[58] PINA C, PINTP F, FEIJO JA, BECKER JD. Gene family analysis of the Arabidopsis pollen transcriptome reveals biological implications for cell growth, division control, and gene expression regulation. Plant Physiol 2005; 138: 744-756.

[59] POPŁOŃSKA K, WOJTCZAK A, KWIATKOWSKA M, KAŹMIERCZAK A. Cytochemical and immunocytochemical studies of the localization of histones and protamine-type proteins in spermatids of Chara vulgaris and Chara tomentosa. Folia Histochem Cytobiol 2007; 45: 367-374.

[60] RATO C, MONTEIRO D, HEPLER PK, MALHÓ R. Calmodulin activity and cAMP signalling modulate growth and apical secretion in pollen tubes. Plant $J$ 2004; 38: 887-897. 
[61] ROBERTSON WR, CLARCK K, YOUNG JC, SUSSMAN MR. An Arabidopsis thaliana plasma membrane proton pump is essential for pollen development. Genetics 2004; 168: 1677-1687.

[62] RODRIGUEZ-PEÑA JM, RODRIGUEZ C, ALVAREZ A, NOMBELA C, ARROYO J. Mechanisms for targeting of the Saccharomyces cerevisiae GPI-anchored cell wall protein Crh2p to polarized growth sites. J Cell Sci 2002; 115: 2549-2558.

[63] ROTMAN N, DURBARRY A, WARDLE A, YANG WC, CHABOUD A, FAURE JE, BERGER F, TWELL D. A novel class of MYB factors controls sperm cell formation in plants. Curr Biol 2005; $15: 244-248$.

[64] ROUDIER F, FERNANDEZ AG, FUJITA M, HIMMELSPACH R, BORNER GHH, SCHINDELMAN G, SONG S, BASKIN TI, DUPREE P, WASTENEYS GO, Benfey PN. COBRA an Arabidopsis extracellular glycosyl-phosphatidyl inositol-anchored protein, specifically. controls highly anisotropic expansion through its involvement in cellulose microfibril orientation. Plant Cell 2005; 17: 1749-1763.

[65] ŠAMAJ J, MÜLLER J, BECK M, BÖHM N, MENZEL D. Vesicicular trafficking, cytoskeleton and signalling in root hairs and pollen tubes. Trends Plant Sci 2006; 11: 594-600.

[66] SAUTER M, VON WIEGEN P, LÖRZ H, KRANZ E. Cell cycle regulatory genes from maize are differentially controlled during fertilization and first embryonic cell division. Sex Plant Reprod 1998; 11: 41-48.

[67] SCHINDELMAN G, MORIKAMI A, JUNG J, BASKIN TI, CARPITA NC, DERBYSHIRE P, MCCANN MC, BENFEY PN. COBRA encodes a putative GPI-anchored protein, which is polarly localized and necessary for oriented cell expansion in Arabidopsis. Genes Dev 2001; 15: 115-1127.

[68] SCHIØTT M, ROMANOWSKY SM, BAEKGAARD L, JAKOBSEN MK, PALMGREN MG, HARPER JF. A plant plasma membrane $\mathrm{Ca}^{2+}$ pump is required for normal tube growth and fertilization. Proc Natl Acad Sci USA 2004; 101: 9502-9507.

[69] SCHMID M, UHLENHAUT NH, GODARD F, DEMAR M, BRESSAN R, WEIGEL D,

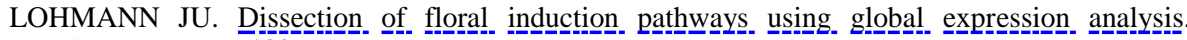
Development 2003; 130: 6001-6012.

[70] SCHNEIDEREIT A, SCHOLZ-STARKE J, BÜTTNER M, Functional characterization and expression analyses of the glucose-specific AtSTP9 monosaccharide transporter in pollen of Arabidopsis. Plant Physiol 2003; 133: 182-190.

[71] SCHNEIDEREIT A, SCHOLZ-STARKE J, SAUER N, BÜTTNER M. AtST11, a pollen tube specific monosaccharide transporter in Arabidopsis. Planta 2005; 221: 48-55.

[72] SHEORAN IS, ROSS AR, OLSON DJ, SAWHNEY VK. Proteomic analysis of tomato. (Lycopersicon esculentum) pollen. J Exp Bot 2007; 58: 3525-3535.

[73] SIVITZ AB, REINDERS A, WARD JM. Arabidopsis sucrose transporter AtSUC1 is important for pollen germination and sucrose-induced anthocyanin accumulation. Plant Physiol 2008; 147: 92100.

[74] SUEN DF, WU SSH, CHANG CHANG H, DHUGGA KS, HUANG AHC. Cell wall reactive proteins in the coat and wall of maize pollen. J Biol Chem 2003; 278: 43673-43681.

[75] TAKAHASHI T, MU JH, GASCH A, CHUA NH. Identification by PCR of receptor-like protein kinases from Arabidopsis flower. Plant Mol Biol 1998; 37: 587-596

[76] TANG W, KELLEY D, EZCURRA I, COTTER R, MCCORMICK S. LeSTIG1, an extracellular binding partner for the pollen receptor kinases LePRK1 and LePRK2, promotes pollen tube growth in vitro. Plant $J$ 2004; 39: 343-353.

[77] TWELL D, OH SA, HONYS D. Pollen development, a genetic and transcriptomic review. [w] Malhó R [red.] The pollen tube. A cellular and molecular perspective. Berlin, Springer-Verlag, Plant Cell Monographs 2006; 3: 15-45.

[78] VAILLANT I, SCHUBERT I, TOURMENTE S, MATHIEU O. MOM1 mediates DNAmethylation-independent silencing of repetitive sequence is Arabidopsis. EMBO Rep 2006; 7: 1273-1278.

[79] VANDEPOELE K, RAES J, DE VEYLDER L, ROUZÉ P, ROMBAUTS S, INZÉ D. Genome-wide analysis of core cell cycle genes in Arabidopsis. Plant Cell 2002; 14: 903-916.

[80] VANTARD M, BLANCHOIN L. Actin polymerization processes in plant cells. Curr Opin Plant Biol 2002; 5: 502-506. 
[81] VAZQUEZ F. Arabidopsis endogenous small RNAs: highways and byways. Trends Plant Sci 2006; 11: 460-468.

[82] VERELST W, TWELL D, DE FOLTER S, IMMINK R, SAEDLER H, MÜNSTER T. MADScomplexes regulate transcriptome dynamics during pollen maturation. Genome Biol 2007; 8: R249.

83] WANG ML, HSU CM, CHANG LC, WANG CS, SU TH, HUANG YJ, JIANG L, JAUH GY, Gene expression profiles of cold-stored and fresh pollen to investigate pollen germination and. growth. Plant Cell Physiol 2004; 45: 1519-1528.

[84] WANG Y, ZHANG WZ, SONG LF, ZOU JJ, SU Z, WU WH. Transcriptome analyses show show changes in gene expression to accompany pollen germination and tube growth in Arabidopsis. Plant Physiol 2008; 148: 1201-1211.

[85] WENGIER D, VALSECCHI I, CABANAS ML, TANG WH, McCORMICK S, MUSCHIETTI J. The receptor kinases LePRK1 and LePRK2 associate in pollen and when expressed in yeast, but dissociate in the presence of style extract. Proc Natl Acad Sci USA 2003; 100: 6860-6865.

[86] ZIENKIEWICZ K, SMOLIŃSKI DJ, BEDNARSKA E. Distribution of poly(A)RNA and splicing machinery elements in Hyacinthus orietalis L. pollen grains and pollen tubes growing in vitro. Protoplasma 2006; 227: 95-103.

[87] ZIENKIEWICZ K, ZIENKIEWICZ A, SMOLIŃSKI DJ, RAFIŃSKA K, ŚWIDZIŃSKI M, BEDNARSKA E. Transcriptional state and distribution of poly(A) RNA and RNA polymerase II in differentiating Hyacinthus orientalis L. pollen grains. Sex Plant Rep 2008; 21: 233-245.

Corresponding author: Katarzyna Rafinska

Department of Cell Biology, Institute of General and Molecular Biology, Faculty of Biology and Earth Sciences, Nicolaus Copernicus University

9 Gagarina Str., 87-100 Torun

phone: +4856 6114454

e-mail:katraf@umk.pl

home address: 87-400 Golub-Dobrzyn, 55 Wojska Polskiego Str. 